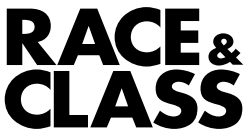

SAGE

Los Angeles,

London,

New Delhi,

Singapore,

Washington DC,

Melbourne

\title{
Failing victims, fuelling hate: challenging the harms of the 'Muslim grooming gangs' narrative
}

\author{
ELLA COCKBAIN and WAQAS TUFAIL
}

Abstract: 'Muslim grooming gangs' have become a defining feature of media, political and public debate around child sexual exploitation in the UK. The dominant narrative that has emerged to explain a series of horrific cases is misleading, sensationalist and has in itself promoted a number of harms. This article examines how racist framings of 'Muslim grooming gangs' exist not only in extremist, far-right fringes but in mainstream, liberal discourses too. The involvement of supposedly feminist and liberal actors and the promotion of pseudoscientific 'research' have lent a veneer of legitimacy to essentialist,

Ella Cockbain is an associate professor at University College London in the Department of Security and Crime Science and a visiting research fellow at Leiden University. Her research focuses on human trafficking, child sexual exploitation and labour exploitation. In seeking evidenceinformed responses to complex issues, she has worked closely with organisations across the public, private and third sectors. Her book Offender and Victim Networks in Human Trafficking was published by Routledge in 2018.

Waqas Tufail is a senior lecturer in Criminology at Leeds Beckett University. His research interests concern the policing, racialisation and criminalisation of marginalised and minority communities and the lived experiences of Muslim minorities. He is a board member of the International Sociological Association Research Committee on Racism, Nationalism, Indigeneity and Ethnicity, serves on the editorial board of Sociology of Race and Ethnicity and is co-editor of Media, Crime, Racism (Palgrave Macmillan, 2018). 
Orientalist stereotypes of Muslim men, the demonisation of whole communities and demands for collective responsibility. These developments are situated in the broader socio-political context, including the far Right's weaponisation of women's rights, the 'Islamophobia industry' and a long history of racialising crime. We propose alternative ways of understanding and responding to child sexual exploitation/abuse. We contend that genuinely anti-racist feminist approaches can help in centring victims/survivors and their needs and in tackling serious sexual violence without demonising entire communities.

Keywords: anti-Muslim racism, anti-racist feminism, child sexual abuse and exploitation, grooming gangs, Islamophobia, Quilliam

\section{Introduction}

Over the past decade, the 'Muslim grooming gangs' narrative has become firmly established in popular and political discourse in the UK. Claims of how Muslim culture and faith supposedly perpetuate sexual abuse have helped collectively demonise British Muslim communities, especially young Muslim men. Initially driven by the rightwing media, this construction has been advanced and legitimised by ostensibly liberal and feminist actors. Additional boosts have come via discredited, highly-politicised and partisan 'research' from special interest groups, apparently seeking to capitalise on wider anti-Muslim attitudes in order to influence government policy and otherwise profit. The 'Muslim grooming gangs' trope has enduring currency among rightwing and liberal political elites and, if left unchecked, risks fuelling further racialised and alarmist news coverage and informing misguided and harmful responses. Much of the narrative has centred around towns in the North and Midlands regions of England, where many particularly high-profile criminal convictions have taken place. Rotherham, in South Yorkshire, has arguably become the place most synonymous with 'Muslim grooming gangs' and has attracted the most attention from far-right groups. Home to a significant population of Asian Muslim heritage, workers from the Indian subcontinent initially arrived into towns such as Rotherham to work within the manufacturing sector and were often treated poorly in comparison to whites. ${ }^{1}$ Like many other places in the former industrial heartlands in the North, Rotherham has struggled for decades with the effects of deindustrialisation - the loss of skilled, well-paid jobs, soaring unemployment and the destabilisation and fragmentation of communities. ${ }^{2}$

The central argument of the 'grooming gangs' narrative is, in short, that a 'disproportionate' number of Asian/Muslim/Pakistani-heritage men are involved in grooming (mostly) white British girls for organised sexual abuse. These claims are often substantiated with reference to a spate of high-profile prosecutions of socalled 'grooming gangs' in towns and cities such as Rotherham, Rochdale, Derby, Telford, Oxford, Huddersfield and Newcastle. The offenders in question - and 
undoubtedly many more - have absolutely committed horrific crimes; this article is categorically not about denying their existence, belittling their harms or otherwise excusing the inexcusable. The term 'grooming gangs', however, is itself a spurious media construct and one that has been heavily racialised from the very start. ${ }^{3}$ 'Grooming gangs' simply do not correspond to established legal or social scientific categories and the various weak definitions offered up by proponents of this racialised narrative fail to delineate these offenders meaningfully from other groups of child sex offenders. ${ }^{4}$ Contrary to stereotypes, there is no 'grooming' offence ${ }^{5}$ - let alone a 'grooming gangs' offence; consequently, 'grooming gang offenders' cannot be sensibly disentangled from police recorded crime data or prosecution data. Moreover, and as will be shown later, a relatively small number of high-profile 'grooming gangs' cases have been used to claim an 'epidemic' of abuse. Despite routinely (and wrongly) being depicted as a 'specific' crime type, 'grooming gangs' are better understood as a vaguely and inconsistently defined subset of child sexual exploitation (CSE) offenders. ${ }^{6}$ Complicating matters further, however, CSE is itself a poorly delineated subset of child sexual abuse (CSA) that spans diverse criminal offences (e.g. rape, sexual activity with a child) - most of which are also used in instances that would not normally be considered CSE. ${ }^{7}$ Existing data simply do not enable reliable assessments of the prevalence or correlates of CSE,, 8 let alone those of 'grooming gangs' - so claims of ethnic or religious disproportionality in 'grooming gangs' are just not testable in any meaningful sense. ${ }^{9}$

The 'grooming gangs' narrative belongs within a broader tendency to racialise crime in political and popular discourse. The classic example is the racialised panic in 1970s Britain in which young black men were cast as 'muggers'. ${ }^{10}$ Fuelled by misleading statistics and misinformation, the devastating consequences included over-policing and criminalisation. In the US, the term 'superpredator' emerged in the 1990s, pushed forward by conservative thinkers as representing a new, hyperviolent crime phenomenon. ${ }^{11}$ As Yamahtta-Taylor reminds us, the use of this term by former Secretary of State and former presidential candidate Hilary Clinton played directly into racist, damaging tropes about young black men: 'The discourse of "super predators" was not an unfortunate misstatement; it was a racist, political calculation intended to publicly demonstrate a lack of sympathy for black people and support for a regime of punishment and retribution.'12

The racialisation of 'grooming gangs' must also be understood in the context of a long history of racialised and gendered Islamophobia, or anti-Muslim racism. Muslim men have been stereotyped as both religiously fanatical and prone to committing violent, sexual acts motivated by a patriarchal, misogynistic culture and backward, barbaric religion. ${ }^{13}$ Looking back over more than a decade, we document the architects of the 'grooming gangs' narrative, examine the political backdrop to it and consider the harms it causes. We also sketch out tangible ways forward, with implications for policy-makers, practitioners and activists. We contend that genuinely practised anti-racist feminism is vital in tackling child sexual abuse and resisting anti-Muslim forces. 


\section{Introducing the key architects of the 'grooming gangs' narrative}

Here, we consider how racialised discourse around 'Asian sex gangs' and 'Muslim rape gangs' emerged, proliferated and became entrenched. We focus on four main architects: media, politicians, the far Right and dubious 'special interest groups'.

\section{The media creates, spreads and sustains a toxic narrative}

'On-street grooming' exploded into the national consciousness on 5 January 2011 when The Times - a rightwing broadsheet owned by Murdoch's News International - ran a dramatic exposé claiming to have uncovered a new crime threat. Setting the bar for subsequent debate, evidence of just fifty-six convicted offenders was used to substantiate alarmist claims of a 'tidal wave of offending'. ${ }^{14}$ The story combined two particularly explosive contentions: that Pakistaniheritage men were preying on white British girls; and that the authorities failed to intervene 'for fear of being branded racist'. ${ }^{15}$ The Times' portrayal of 'grooming' as a distinct and racialised crime threat rests on 'misconceptions, anecdote, opinion and the deliberate manipulation of limited statistics of dubious provenance ${ }^{\prime}{ }^{16}$ Nevertheless, the coverage proved inflammatory and has set the news agenda in the decade since.

The journalist behind the story was a little-known regional correspondent called Andrew Norfolk. Soon promoted to The Times' Chief Investigative Reporter, Norfolk pursued 'grooming'-related stories doggedly over the coming years, combining major scoops with less obviously newsworthy stories seemingly chosen to stoke 'his personally crafted crime model of white victims and Pakistani perpetrators' ${ }^{17}$ He subsequently received some of the most prestigious awards in British journalism, including the Orwell Prize and Paul Foot Award. A series of discredited articles led Cathcart and French to examine whether Norfolk was sacrificing journalistic standards in a push to present 'Muslims as threatening'. ${ }^{18}$ Their rigorous analysis of three major stories - two 'grooming'-related and the now infamous 'Muslim foster care' 19 scandal - concluded that his central allegations were 'unfounded', 'serious inaccuracies' rife, 'standards of conduct and ethics' severely breached and 'Norfolk's impartiality' highly questionable. ${ }^{20}$ Editor John Witherow was complicit too, they argued, as the newspaper had 'vigorously promoted Norfolk's accusations, placing them on its front page, endorsing them in editorials and subsequently resisting complaints and criticisms in defiance of the evidence' ${ }^{21}$ Maintaining this trend, The Times dismissed the forensic critique as a 'politically motivated' attempt to 'smear and suppress fine reporting' ${ }^{22}$

His dubious journalistic standards notwithstanding, Norfolk's racialised crime threat immediately caught the media, political and public imagination and soon became entrenched. ${ }^{23}$ Phrases like 'grooming gang' have come to assume a particular and racially loaded meaning. Even a cursory news database search demonstrates how a new vocabulary emerged post-Times exposé: the term 'grooming 
gang ${ }^{* \prime}$ returned 5,647 results in the nearly nine years since then, compared with zero in the nine years prior. ${ }^{24}$ The term's racialisation was as evident as its proliferation: over half the results contained references to 'Islam ${ }^{* \prime}$, 'Muslim ${ }^{* \prime}$, 'Pakistan ${ }^{* \prime}$ or 'Asian ${ }^{*} .{ }^{25}$ Indicating how this loaded language has leached even into professional discourse, the Crown Prosecution Service (CPS) recently issued a press release headlined 'Six men convicted of Rotherham grooming gang offences': to reiterate, 'grooming gang offences' do not exist in law. ${ }^{26}$

Several academics have criticised the disparity between media portrayals of 'Asian sex gangs' and similarly high-profile white offenders, including celebrities and politicians. ${ }^{27}$ According to Miah, ${ }^{28}$ sexual abuses carried out by Asian offenders are explained in terms of race and culture, whereas their white counterparts' crimes are framed as individual deviance.

\section{Politicians give credibility to racial stereotypes around 'grooming'}

Numerous mainstream politicians have helped propagate the 'grooming gangs' narrative through clumsy, misleading and/or outright racist contributions. Centre-left politicians have proved particularly pivotal in migrating rhetoric more characteristic of the far Right to the political mainstream. ${ }^{29}$ Key early contributions came from Labour MP Jack Straw: despite apparent disinterest in CSE while home secretary, ahead of a critical by-election he notoriously blamed 'grooming' on regressive British-Pakistani culture, arranged marriages and views of white girls as 'easy meat'. ${ }^{30}$ His comments not only farcically implied that raping children is the natural alternative to premarital sex ${ }^{31}$ but furthered myths that 'repressed sexuality' drives abuse and perpetrated Orientalist stereotypes about Muslim men's 'rapacious sexual appetites' ${ }^{32}$ Other Labour politicians followed suit in emphasising the role of ethnicity and/or culture. ${ }^{33}$ Such spurious 'cultural' explanations have been criticised both within and beyond the context of CSE as a backdoor for 'new racism' in a supposedly 'post-racial' society. ${ }^{34}$

One particularly dramatic intervention came from Sarah Champion, Labour MP for Rotherham and, ironically, shadow secretary of state for women and equalities. Champion had to resign from the frontbench after writing an inflammatory article entitled 'British Pakistani men ARE raping and exploiting white girls . . . and it's time we faced up to it' for The Sun, a News International-owned rightwing tabloid. ${ }^{35}$ Champion wrote, 'These people are predators, and the common denominator is their ethnic heritage', claiming she was speaking out as she could no longer 'shy away from doing the right thing by fearing being called a racist'. Her views in this article were likened to those of the far Right, and she faced intense criticism including from some of her parliamentary colleagues and from local human rights groups in her Rotherham constituency. ${ }^{36}$ Champion later apologised for her 'extremely poor choice of words', admitting the article 'could be taken to vilify an entire community' ${ }^{37}$ Her article notably appeared alongside and was endorsed by a column from The Sun's former political editor Trevor Kavanagh, which characterised 'grooming gangs' as 'the Muslim problem': a framing heavily criticised for evoking 
Nazi-era rhetoric. ${ }^{38}$ Kavanagh's article attracted official complaints but was cleared by the Independent Press Standards Organisation (IPSO), which found it did not breach its guidelines. Kavanagh serves as a member of IPSO's regulatory board, although the body claimed he was not part of the investigation. The decision to clear Kavanagh's article was condemned by both the Muslim Council of Britain and the Board of Deputies of British Jews, which said the decision highlighted that IPSO was 'unfit for purpose'. ${ }^{39}$

Conservative MP Sajid Javid, then communities secretary and now chancellor of the exchequer, vocally defended Champion's contribution and the need to examine 'racial motivation'. ${ }^{40}$ The following year, Champion spearheaded a letter ${ }^{41}$ to Javid - by then home secretary - co-signed by twenty MPs, demanding research into the 'drivers' of 'organised grooming gangs'. ${ }^{42}$ The letter explicitly mentioned neither race nor religion, but by now 'grooming gangs' was clearly a racially coded term. An interfaith group's follow-up letter supported Champion's demands, explicitly citing dubious evidence of ethnic disproportionality to bolster claims of a 'sexual grooming gang epidemic'. ${ }^{43}$ Javid's response to Champion was scooped by The Times' aforementioned Andrew Norfolk and reported as the home secretary having 'ordered research into why men convicted of grooming-gang sex crimes are disproportionately of Pakistani origin'. ${ }^{44}$ Although this angle misrepresented Javid's actual letter, it was repeated across numerous news outlets - and neither Javid nor Champion apparently cared to correct it. ${ }^{45}$ Consequently, the impression stood that ethnic disproportionality in 'grooming gangs' was an accepted fact and legitimate focus for government-commissioned research.

Fuelling the fire, Javid later released a dog-whistle of a tweet about 'sick Asian paedophiles'. ${ }^{46}$ His propagation of racial stereotypes is particularly important given his senior roles and British-Pakistani heritage: 'racial gatekeeping' lends social legitimacy to claims and policies that disadvantage racially marginalised groups. ${ }^{47}$ Notably, Javid's interest in racialising sexual offending has not extended to organised abuse in schools, religious institutions, sports clubs, politics, celebrity circles and other contexts likely dominated by white offenders. Contributions to a recent House of Lords debate exemplify how politicians continue to stoke misleading narratives around 'grooming gangs', perhaps to further broader agendas of their own. Lord Singh, an independent peer who soon after quit the BBC over claims it was trying to silence him for fear of offending Muslims, ${ }^{48}$ decried 'misplaced political correctness'. Baroness Cox, who previously lost the Conservative whip after urging voters to support UKIP, ${ }^{49}$ appealed to collective responsibility, saying 'Muslim leaders' should 'take ownership of policies to prevent these atrocities'. Lord Cormack exceptionalised 'grooming gangs', treating them as emblematic of an entire community:

... it is deeply distressing that these people are disgracing themselves and their wider community, as well as the British community of which they have become a part. ${ }^{50}$ 
The far Right embrace a made-to-measure Muslim threat

The far Right's enthusiasm for the 'Muslim grooming gangs' narrative is predictable. Yet, their messaging and activity feeds off and is given credence by racialising discourses already in circulation among mainstream politicians. Further underlining how ideas can migrate in both directions between parliament and far-right street forces, the extremist British National Party (BNP) was an original proponent of racialising CSE in the early 2000s. ${ }^{51}$ Since then, 'Muslim grooming gangs' have become a staple of far-right propaganda in the UK and beyond, forming a key 'mobilising trope' of the pan-European Counter-Jihad Movement. ${ }^{52}$ Overtly Islamophobic terms like 'rape jihad' play to fears of invasion and 'cultural replacement'. The far Right's weaponisation of CSE is much facilitated by needing only to echo and embellish tropes well-established in the mainstream. For example, far-right propaganda text Easy Meat features familiar claims about the 'epidemic of child-rape by grooming gangs', failed multiculturalism, politically-correct cover-ups and the 'collusion' and collective responsibility of 'the Muslim community'. ${ }^{53}$ Notably, its author Peter McLoughlin later self-published the book Mohammed's Koran: why Muslims kill for Islam, delisted by Amazon for its 'inappropriate content'. ${ }^{4}$ His co-author on the latter was 'Tommy Robinson' (real name Stephen Yaxley-Lennon): ex-English Defence League (EDL) leader and 'rock star' of the transatlantic and pan-European 'counter-jihad' movement. ${ }^{55}$

In recent years, 'Tommy Robinson' has made CSE into his cause célèbre. He was recently appointed 'special personal advisor on rape gangs' to the leader of the UK Independence Party (UKIP) ${ }^{56}$ and invited to speak in the Czech Parliament about 'grooming gangs' ${ }^{57}$ Of course, Robinson is neither the subject matter expert nor victims' champion he claims to be. His outspokenness on child sexual abuse apparently does not extend to offences committed by fellow EDL extremists. ${ }^{58} \mathrm{He}$ was also imprisoned for contempt of court after breaching reporting restrictions at a major CSE trial in Huddersfield. ${ }^{59}$ Testifying in sexual offences trials is already notoriously difficult and traumatic - even without the additional stress, delays and even appeals that such breaches of due process can cause. ${ }^{60}$ Robinson's acts were the latest in a long history of the far Right disrupting CSE trials by putting their own self-interests (promoting racism, publicity, campaign material, etc.) ahead of victims' welfare and the administration of justice. ${ }^{61}$

\section{'Special interest' groups provide the missing 'research'}

Stereotypes of 'Muslim rape gangs' were greatly boosted by the Quilliam Foundation's 'grooming gangs' report, source of the spurious but ubiquitous claim that ' $84 \%$ of grooming gang offenders' are Asian. ${ }^{62}$ Although framed as 'academic' 63 and 'evidence-based', the report is shoddy pseudoscience. Its conclusion that the 'over-representation of Asian-ethnicity (predominantly British Pakistani origin) individuals . . is conclusively irrefutable' (p. 6) is deeply misleading. The report in no way delivers on its pretence of 'comprehensive data analysis of all group child-sex offences committed in the United Kingdom over 
a period of 12 years' (p. 15). Tellingly, the key word 'comprehensive' was later deleted amid furtive corrections to the published report: when challenged, staff outright lied ${ }^{64}$ and continued to meet valid criticisms with personal attacks. ${ }^{65}$ The supposedly 'specific crime profile' 66 under investigation is actually confused, inconsistent and incoherent. ${ }^{67}$ The report is exceptionally weak methodologically: instead of disclosing fundamentals like sources, sampling strategy, search terms (if any) and inclusion parameters, we find vacuous assertions of 'extensive data mining methods' (p. 16). Bizarrely, its 'data' section is primarily a crude rehashing of results from an entirely different report divested of crucial caveats about its limitations. ${ }^{68}$

Somehow - in a way impossible to verify - 264 offenders were identified across twelve years: horrific abuse notwithstanding, such a sample does not justify dramatic claims of an 'epidemic' and 'crisis' (pp. 14, 33, 41). The data source remains unspecified but was likely media reports, seemingly cherry-picked to 'definitively demonstrate' a predetermined disproportionality (p. 15). Using media coverage to assess sexual offenders' characteristics is problematic in any case, since offences by ethnic minorities tend to be over-reported: 69 a form of 'deviance amplification'..$^{70}$ Worryingly, some academics (including the author of a book on 'anti-racist practice in social work') have since uncritically cited Quilliam's drivel and even made a similarly dubious attempt to assess (dis)proportionality in CSE offending based on 'Muslim names' in media reports. ${ }^{71}$ This point further demonstrates that poor quality, partisan 'research' also has the capacity to influence and shape scholarly debate - a development that should alarm researchers.

Quilliam's report and its 'data analysis' is basic counting at best, devoid of the transparency and rigour needed for any confidence in the findings. Despite the complete absence of statistical reporting around victims' characteristics or offenders' religion/national heritage, the authors contend that offenders were 'predominantly British Pakistani origin' and the 'Asian male/ white female, perpetrator-victim dynamic is the undeniable prominent feature' (pp. 6, 30). Their claims to 'list all possible caveats relating to the accuracy of the data' and to have made 'every attempt' to 'ensure the integrity of the information' (p. 16) are patently untrue: obvious biases (e.g. sampling, self-selection, institutional or media biases) are overlooked and there is no sign of peer-review or any meaningful quality assurance. In fact, the report is riddled with untrue, misleading, contradictory, unsubstantiated and misattributed information. ${ }^{72}$ Information appears cherry-picked to support a central thesis that 'regressive' Pakistani culture drives abuse of white British girls. For example, the authors claim 'racial difference ... [is] highlighted through repeated reference to the 'whiteness' of the victims' (p.7) but provide relevant supporting evidence for just one offender, thus grossly generalising from under 0.4 per cent of their sample. Similarly, they conveniently omit relevant court judgments that challenge racial/cultural explanations. ${ }^{73}$ Further underlining their cavalier approach, the authors make sweeping, unsubstantiated claims that 'grooming' is caused by 'divisive, unevolved 
cultural identities', unchecked cultural misogyny, homophobia, insufficient integration of migrants, child marriage, and so on (p. 32). The 'regressive left' and 'extreme political correctness' are duly blamed as well (pp. 40-41). Failing to declare funding or conflicts of interests is also problematic: this 'counter-extremism think tank' has a history of dubious funding and alliances, including partnering with 'Tommy Robinson' in his ill-fated 'de-radicalisation' and stood to gain from CSE being reconceptualised as a 'counter-extremism' threat. ${ }^{74}$

Despite its interminable flaws, the Quilliam report attracted immediate, extensive and almost entirely uncritical publicity. ${ }^{75}$ Playing into existing stereotypes, it provided the veneer of academic and statistical legitimacy largely missing to date. Some outlets further amplified the threat of the Muslim 'other' by misrepresenting the already spurious results as pertaining to all 'grooming': for example, The Sunday Times was found to breach reporting codes with its misleading headline 'Asians make up 80 per cent of child groomers' ${ }^{76}$ In foregrounding their British-Pakistani heritage in the report and subsequent publicity, the Quilliam authors predictably helped detract from their lack of relevant academic or professional credentials and empowered responses like this one:

Islamophobia! Up goes the cry to quickly shut down debate. Sorry but that won't wash on this occasion. The Quilliam report is written by Haris Rafi [sic] and Muna Zainab, both of Pakistani heritage, so it's pretty hard to accuse them of demonizing Muslims. ${ }^{77}$

Demonstrating how the report empowered Islamophobes, one UKIP politician praised 'some very courageous Muslims in the Quilliam Foundation' and their work tracing abuse 'back to the Islamic faith' when declaring that the UK faced 'a holocaust of our daughters' ${ }^{78}$ Another repeatedly cited it in the House of Lords to bolster his own claims of 'millions of rapes of white and Sikh girls by Muslim men' and '250,000 victims of radical Muslim grooming gangs' ${ }^{79}$ The 84 per cent statistic is regularly found in far-right materials on- and off-line. 'Tommy Robinson' even included Quilliam's report in his defence bundle, apparently to suggest his claims about 'grooming' were 'factually correct' and so would not have prejudiced the Huddersfield trial. ${ }^{80}$

The fringe, nationalist Sikh Youth UK (SYUK) group then released a much lower-profile but similarly shoddy report, which addressed 'religiously aggravated sexual exploitation of young Sikh women'. ${ }^{81}$ SYUK had already been accused of propagating anti-Muslim hatred in collaborating with 'Tommy Robinson' around 'Muslim grooming gangs' ${ }^{82}$ Further underlining how actors have forged questionable alliances around shared interests in the 'grooming' space, Sarah Champion MP - author of the racist article discussed earlier and much lauded by Quilliam ${ }^{83}$ - backed both SYUK's inflammatory report ${ }^{84}$ and its broader contested work around CSE. ${ }^{85}$ The report was promoted across social and traditional media and at gurdwaras, where SYUK solicits donations. ${ }^{86}$ Effectively a diatribe against Pakistani Muslims, this empirically and analytically 
weak publication makes inflammatory yet poorly substantiated claims of a 'grave, longstanding and targeted threat of sexual abuse and exploitation' and the attendant 'failures of law enforcement agencies and local authorities' ${ }^{87}$ Its underlying appeals to historical tensions and Islamophobia recall Sian's ${ }^{88}$ critiques of the 'forced conversion' narrative, which has proven potent and durable among British Sikh diaspora communities despite there being no evidence of 'predatory' Muslim males grooming 'vulnerable' Sikh girls for conversion. Ironically, given the focus on sexual violence, women are implicitly treated in the SYUK report as possessions and a locus of shame and honour. Similar criticisms have been levied at the broader 'grooming' discourse among British Sikhs, with female Sikh activists complaining that women's voices have been side-lined, familial abuse overlooked and women's experiences misappropriated 'to prop up their personal anti-Muslim agenda'. ${ }^{89}$ Despite its obvious shortcomings, the SYUK report was cited uncritically in a recent parliamentary debate on 'grooming gangs'.$^{90}$

\section{Driving anti-Muslim racism: the UK and international far Right}

To understand the broader political context to the 'grooming gangs' discourse, it is important to consider the international far Right's weaponisation of women's rights, the role of the UK far Right and the 'Islamophobia industry'.

\section{How the international far Right is co-opting women's rights}

Central to pan-European and indeed global far-right narratives is the presentation of Muslims as a specific and urgent civilisational threat. ${ }^{91}$ Far-right propaganda commonly refers to the 'Islamisation' or 'Islamification' of Europe, or 'Islamofascism'. ${ }^{92}$ The 'war on terror' helped mainstream such perspectives and normalise the use of secular and feminist discourses to inveigh against the supposedly increasing threat of Islam in Europe. ${ }^{93}$ The anti-Muslim political climate cultivated by 'Islamofascism' proponents has helped fuel concerted campaigns against face veils (leading to full or partial bans in several European countries), concerns over the 'Muslim birth rate', frequent attacks on Muslim civil society groups and political activists, concocted outrage over the practice of halal slaughter and a persistently anti-Muslim 'integrationism' agenda. ${ }^{44}$ This anti-Muslim climate has served as ideological justification for domestic and international 'war on terror' efforts - and the attendant wide-ranging human rights abuses - of which Muslims in Europe, the US and elsewhere bear the brunt. ${ }^{95}$ A defining feature of European far-right propaganda, which has now seeped into mainstream liberal and some feminist discourse and is particularly important for this article, is the use of women's rights to advocate and advance anti-Muslim sentiments.

A clear tendency has emerged for far-right, neo-nationalist parties - and groups and individuals affiliated with their cause - to present themselves as champions of women's rights. ${ }^{96}$ This phenomenon is apparent in various European countries and beyond, including the Nordic bloc, where societies are stereotyped as more 
tolerant and social democratic in their value systems. In the Nordics, as in the UK, serious sexual offences have been racialised and politicised. ${ }^{97}$ For example, three high-profile cases in Finland were exploited to rail against immigration policy, Muslims and those regarded as 'threatening others'.$^{98}$ These cases also demonstrate how nationalist and colonialist rhetoric serves to symbolise 'their' women as representing the honour and glory of a nation and further links women's bodies with territory and notions of a 'pure' biological race. ${ }^{99}$ Similar invocations are evident in other countries and contexts, including in France and Australia. For example, Dagistanli and Grewal contend that in public and political discourse in Australia, a series of rapes came to represent both the perceived danger of Muslim immigrants and their threat to 'Australian values': 'the violation of "Australian girls" became symbolic of a much larger threat to the nation'. 100

In her work on 'femonationalism', ${ }^{101}$ Farris contends that both nationalists and neoliberals frame Islam as 'a quintessentially misogynistic religion and culture' and draw on gender equality to 'advance xenophobic and racist politics'. Through case studies from the Netherlands and Italy, Farris explores the unlikely coalition of nationalists and feminists around an anti-Muslim agenda, demonstrating how some feminists and femocrats ${ }^{102}$ are complicit in campaigning that helps stigmatise Muslim men and which often also includes a broader anti-immigrant component. Such context helps situate and make sense of the contributions of prominent feminists in racialising 'grooming gangs': most notably the inputs of Sarah Champion MP, explored earlier in this article. Such interventions from individuals seen as feminists from the liberal 'centre ground' of politics are crucial in legitimising the far Right's campaign against 'grooming gangs': serving to strengthen the brand of anti-Muslim racism positioned under the banner of gender equality.

\section{The UK far Right and the 'Islamophobia industry'}

The EDL, the racist anti-Muslim street group founded by 'Tommy Robinson', enjoyed its greatest success and biggest mobilisations in the early 2010s. EDL demonstrations, often targeted at the UK's Muslim communities, then regularly attracted thousands of participants. The EDL has since imploded, reportedly due to dwindling support and in-fighting. ${ }^{103}$ As is common in far-right circles, however, various smaller, splinter groups have emerged to accommodate street-based fascist thugs. The remnants of the EDL, including groups such as 'Yorkshire's Finest', have targeted Rotherham, which has experienced numerous far-right demonstrations in the aftermath of the 'grooming gang' scandals: over one particularly active period - August 2014-September 2015 - fourteen separate demonstrations took place. ${ }^{104}$ One such group, the 'Democratic Football Lads Alliance (DFLA), organises almost exclusively against 'Muslim grooming gangs', under the guise of women's rights and protecting (white) women and girls. ${ }^{105}$ Notably, the DFLA add credence to their claims by using on their flyers the dodgy 84 per cent statistic from Quilliam and emphasising that even 'left-wing media news outlets' publicised it, implying it must therefore be true. ${ }^{106}$ Another new group, 
'Justice for Women and Children', is reportedly the UK's first female-led far-right group. It was launched in Sunderland in the North East and claims to campaign against abusers and for victims regardless of ethnicity: yet, members and their close associates have attracted accusations of 'long term associations with the farright'. ${ }^{107}$ Commenting on a BBC News investigation into 'Justice for Women and Children', Sarah Champion MP rather ironically and hypocritically condemned them for 'using some of the most abhorrent abuse of children for their own agenda'. When 'Tommy Robinson' was tried for contempt of court (see previous section), Ezra Levant and Katie Hopkins attended in support: prominent far-right figures, notorious for their frequent anti-Muslim diatribes. ${ }^{108}$ Further underlining the reach of powerful 'special interest groups' invested in furthering an anti-Muslim agenda, 'Tommy Robinson' was 'reporting' for far-right Canadian news website Rebel Media at the time of the offences. 'Robinson's' work for Rebel Media was revealed as funded via a fellowship from US tech billionaire Robert Shillman, ${ }^{109}$ a board member of the notoriously anti-Muslim thinktank the David Horowitz Freedom Center. Giving a glimpse into a transatlantic web of dark money and influence, ${ }^{110}$ both the David Horowitz Freedom Center and Quilliam have received funds from the Lynde and Harry Bradley Foundation. ${ }^{111}$ Scholars have referred to such groups as being part of an 'Islamophobia industry': transatlantic neoconservative actors and institutions, often funded by wealthy elites, which work to 'manufacture' fear of Islam and Muslims in order to influence political discourse and policy. ${ }^{112}$

\section{Examining the impacts of racialising child sexual abuse}

Although it is very difficult to pinpoint how racialised discourses contribute to specific outcomes (e.g. racist violence), ${ }^{113}$ a growing body of evidence suggests the fixation on 'Muslim grooming gangs' is making its effects felt locally, nationally and internationally. Here, we explore how it can skew responses to CSE/CSA, affect victims, fuel violent Islamophobia and translate into structural racism.

\section{Increased attention to CSE but a heavily-skewed focus}

Over the past decade, CSE has gone from a fairly marginal concern to being designated a 'national threat'. 114 Publicity, political exposure and outrage around 'grooming gangs' have helped drive considerable changes, including new enquiries and strategies, ${ }^{115}$ a revised definition, greater prioritisation and investment in improving responses and expanding the evidence-base. The number of recorded child sex offences in general has increased rapidly since 2012/13, reaching 63,000 across the UK in 2016/17. ${ }^{116}$ This uptick, driven particularly by nonrecent cases, likely reflects increased awareness of CSE/CSA, greater willingness to report, improved understanding among professionals and better recording practices. ${ }^{117}$ The intersection between CSE and other harms is also increasingly recognised, including going missing, youth offending, human trafficking and 
child criminal exploitation. ${ }^{118}$ Once routinely dismissed as 'streetwise' and 'consenting child prostitutes' ${ }^{119}$ sexually exploited children now appear more widely recognised as victims of abuse. ${ }^{120}$ Responding to attitudinal changes and calls to reduce victim-blaming, ${ }^{121}$ sexual offence legislation has been revised, replacing the stigmatising term 'child prostitution' with 'sexual exploitation of children'. Although many such developments are clearly to be welcomed, improvements have come at a cost: the narrow lens on 'grooming gangs' detracts from the immense scale and diversity of abuse.

In 2016 alone, 6,687 offenders were convicted of CSA-related offences in England and Wales. ${ }^{122}$ These figures clearly dwarf the select handful of cases underpinning The Times' ${ }^{123}$ and Quilliam's ${ }^{124}$ sensationalist claims of an epidemic: respectively just four and twenty-two convicted offenders per year for the whole UK. ${ }^{125}$ The true epidemic here, of course, is CSA in general: an estimated 15-20 per cent of girls and 7-8 per cent of boys are sexually abused. ${ }^{126}$ CSE/CSA occurs in numerous different contexts and involves diverse victims and offenders, many of whom are family members or friends. ${ }^{127}$ Beyond already debunked 'evidence' from The Times ${ }^{128}$ and Quilliam, ${ }^{129}$ claims of ethnic disproportionality in 'grooming' typically rest on small-scale reports ${ }^{130}$ with obvious methodological shortcomings. ${ }^{131}$ Nevertheless, ethnicity-related results are often decontextualised and, stripped of vital caveats, that extensive missing data mean their findings are not reliable, let alone generalisable. In examining alleged ethnic disproportionality, wide-reaching national datasets with clearer and more consistent inclusion parameters are a better comparator. Although criminal justice data on ethnicity should always be treated cautiously (and data on religion are simply not collected as standard), Asians were notably not overrepresented among the approximately 172,000 men and 27,000 women convicted of sexual offences in England and Wales in 2016. ${ }^{132}$

\section{Erasing victims and survivors and neglecting their needs}

The overwhelming focus on Asian men abusing white girls risks erasing other victims, neglecting their needs and overlooking other offenders. ${ }^{133}$ Clearly demonstrating diversity in those affected by CSE, a study of over 9,000 CSE serviceusers in the UK found that nearly one-third was male and around one in five black or minority ethnicity (BME). ${ }^{134}$ Mainstream services are reportedly geared towards white girls and overlook the needs of other (intersecting) groups like ethnic minorities, boys, LGBTQ+ children and those with disabilities, who can face particular challenges and barriers to disclosure, like additional stigma or fear of 'shaming' their families. ${ }^{135}$

Despite extremely limited empirical research, evidence (some anecdotal) is gradually amassing that the existence, experiences and welfare of victims/survivors who deviate from now entrenched racial stereotypes can be neglected. For example, several prosecutions involving mostly white offenders attracted minimal media coverage compared to that reserved for 'Asian sex gangs': as if their 
abuses somehow mattered less. ${ }^{136}$ The Jay (2014) report received intense publicity for its (methodologically dubious ${ }^{137}$ ) estimate that 1,400 children were abused in Rotherham between 1997 and 2013, mostly by groups of Pakistani-heritage offenders. BME victims were almost entirely overlooked in the coverage. ${ }^{138}$ Meanwhile, Quilliam's report literally whitewashed out BME victims in its sample through untrue and insulting claims that all victims were white. ${ }^{139}$ 'Grooming gangs' are also a hot topic on social media, where numerous people have spoken informally about feeling erased and invalidated because their abuse did not conform to racial stereotypes. The following lines from one survivor's poem exemplify this sense of erasure:

I'm a victim of child abuse by white working class men,

You dismiss it because you look just like them ...

Voices erased to focus solely on one method of abuse

Now deceptive propaganda for third-party use (@CasuallyQ, author) $)^{140}$

Survivors have spoken out against their and others' experiences being weaponised for political gain, particularly by the far Right which uses 'them as a weapon for racism just the same way they were used for sex by their abusers' (@ KateElysiaNWO, author). ${ }^{141}$ Some report experiencing verbal abuse as a result:

Tommy [Robinson] doesn't support the cause I fight for, he peddles hate and right wing extremism in my opinion. . . [@Holly Archer_CSE, author and support worker]. ${ }^{142}$

... The amount of abuse I've had from them for not fitting the agenda/supporting TR [Tommy Robinson] is unbelievable (they were ok talking about my story until they realised I wasn't Abused only by Muslims - then suddenly they felt my kids needed throwing in the English Channel) [@MsCaitSpencer, author]. ${ }^{143}$

Further pushback was evident in an open letter from a group of survivors fed up with repeated far-right marches in Rotherham. ${ }^{144}$ Published on the front page of a local newspaper, it called for the marches to be banned and detailed the anxiety and trauma caused, including 'horrific memories' stirred and frustration at abuse being exploited to fuel 'hatred and fear'. ${ }^{145}$ The far Right, UKIP included, have faced further accusations of co-opting the abused to promote their narrative, trying to 'infiltrate' support groups and even launching an 'anti-grooming helpline' 146 that raises obvious concerns from a safeguarding and data protection perspective. ${ }^{147}$ For example, peer-support group Shatter Boys was reportedly approached by senior UKIP figures promising introductions to multi-millionaire donors, leading founder Danny Wolstencroft to state, 'What they're doing basically is grooming survivor groups and survivors of abuse. I think their fight is about 
Islam. ${ }^{\prime 148}$ Of course, CSE survivors are not a homogeneous group and some survivors and their families have tilted towards the far Right, for example sharing far-right propaganda on social media, speaking at rallies or collaborating on 'anti-grooming' initiatives. ${ }^{149}$ This troubling development highlights how the cynical and populist far Right is able to instrumentalise its anti-Muslim agenda to gain support from unlikely sources.

\section{Fuelling anti-Muslim hostility and violent Islamophobia}

The global far Right has long indulged in anti-Muslim propaganda, including through the racialisation of sexual abuse (see previous section). In diatribes posted online before his massacre of seventy-seven people in Norway in 2011, Anders Breivik railed against Islam, multiculturalism and the rape of 'hundreds of European women'. ${ }^{150}$ The perpetrator of the most recent far-right massacre killed fifty-two Muslims as they prayed in mosques in Christchurch, New Zealand. In specific reference to ' grooming gangs', his ammunition was inscribed 'For Rotherham', visible in images uploaded online before the attack and the livestreamed atrocities themselves. ${ }^{151}$ His rambling 'manifesto' also featured two pages on how 'invading forces' were raping 'European women', drawing extensively on UK CSE cases. ${ }^{152}$ Darren Osborne, who killed a Muslim prayer-goer and injured several more in the Finsbury Park mosque terror attack in 2017, was reportedly 'obsessed with Muslims, grooming gangs, and terrorism' and, according to his former partner, suddenly started accusing all Muslims of 'raping children and being capable of blowing people up'. ${ }^{153}$ Osborne's online searches and interactions included far-right group Britain First and 'Tommy Robinson'. ${ }^{154}$

More generally, far-right activity around ' grooming gangs' has focused on towns in England's North and Midlands, like Rochdale, Rotherham and, increasingly, Telford: home to high-profile convictions. ${ }^{155}$ As highlighted previously, extensive marches targeting Muslim communities have taken place, particularly in Rotherham. Attempts to ban the marches have failed and local residents, including Muslims, trade unionists, anti-fascists and even abuse survivors have spoken out against their detrimental effects. ${ }^{156}$ Anti-Muslim attacks in Rotherham have risen, local communities have been held collectively responsible for the crimes of individuals, young Muslim children report being bullied as 'groomers' and anti-Muslim opinions published as letters in the local press highlight some ways in which the local racial landscape seems radically transformed by the racialisation of the 'grooming gang' cases. ${ }^{157} \mathrm{~A}$ recent study by Britton ${ }^{158}$ has detailed how Muslim men in Rotherham have developed strategies with which to navigate everyday instances of racism brought on by the racialisation of the CSE scandal.

Although so-called 'grooming gang' cases have undoubtedly involved horrific abuses, ${ }^{159}$ it is clear overall that a disproportionate, politicised and racialised panic has emerged, in its most extreme forms helping 'justify' racist murders: alongside the New Zealand massacre just discussed, at the local level an elderly Muslim man and Rotherham resident Mushin Ahmed was beaten to death by 
two of his white neighbours whilst repeatedly being called a 'Paki' and a 'groomer'. Eighty-one-year-old grandfather Ahmed was attacked whilst walking to his local mosque; he was kicked so hard a trainer imprint was left on his face and it was determined that he was targeted 'for no better reason than Mr Ahmed was Asian'. ${ }^{160}$ As we have explored in this article, the term 'groomer' has developed to become a potent racial signifier and term of racist abuse directed squarely at those perceived to be Muslim. ${ }^{161}$

\section{Racial stereotypes can translate into structural racism}

Although targeted research is needed, there is an obvious risk that racial stereotypes around 'grooming' will translate into structural racism and fuel discrimination across safeguarding and criminal justice responses. ${ }^{162}$ Indeed, the Drew Review of South Yorkshire Police's responses to CSE emphasised the dangers of 'too narrow a working definition' of CSE and concluded that an undue focus on 'red light areas . . . and gangs of men principally of Pakistani heritage led not only the force but also probably the whole partnership to look for signs of exploitation in the wrong places'. ${ }^{163}$ Focusing on Asian offenders may lead to visibility and institutional biases, potentially affecting who is investigated, arrested and prosecuted and skewing law enforcement data. The potential for discrimination at court cannot be ruled out either, although large-scale analysis of court verdicts suggested juries do not racially discriminate against sexual offence defendants. ${ }^{164}$ Nevertheless, that research predates widespread racial stereotypes of 'grooming gangs' and future case simulation with juries might usefully focus on this particular issue.

Since 2016, there has been a compulsory CSE 'flag' for police recorded crime data. ${ }^{165}$ Although framed as a step towards improved data collection and analysis, to be most useful such flags should be interpreted and applied consistently. Here, there is an obvious risk that racial stereotyping fuels circular 'proof' of supposed disproportionality. Boundary issues around CSE are a notorious concern, with some professionals worrying that the so-called "grooming and pimping model" has come to define CSE'. ${ }^{166}$ Indeed, the National Crime Agency (NCA) has reportedly identified such inconsistencies 'in reviewing and flagging CSE and CSA' that it prefers to use the umbrella term 'child sexual exploitation and abuse' instead. ${ }^{167}$

Differential investment could also exacerbate the perceived threat of 'grooming gangs'. An obvious example is Operation Stovewood: the UK's largest CSE investigation, led by the NCA with a projected total cost of around $£ 90$ million by $2024 .{ }^{168}$ Initiated in response to the Jay Report, it focuses on abuse in Rotherham between 1997 and 2013 and has resulted in twenty convictions, many conforming to racial stereotypes. Although too limited in number to affect national statistics greatly, these high-profile prosecutions may disproportionately influence public perceptions. 


\section{Articulating alternatives and moving towards anti-racist feminist responses}

In this section, we consider alternative ways of understanding and responding to CSE/CSA and counter-fixes to the misleading and harmful 'grooming gangs' narrative. We also sketch out how a commitment to anti-racist feminism could drive future research, policy and practice, simultaneously prioritising and tackling serious sexual violence while rejecting attempts to racialise the issues and demonise minority communities.

First, too few credible experts in the child protection space have publicly challenged the racialisation of CSE. ${ }^{169}$ More critical engagement with the issue of inaccurate and harmful racial stereotyping is needed from NGOs, policy-makers, practitioners and academics with expertise around child sexual abuse and its prevention. Since they operate from a position of influence and expertise, disengagement around racial stereotyping risks turning into complicity.

Second, a more robust, evidence-informed approach to tackling CSA is evidently needed. Although better data cannot prevent abuse per se, they are crucial in monitoring patterns and trends, informing prioritisation, identifying levers for intervention and evaluating counter-measures. Calls for a national CSA prevalence survey are therefore welcome. ${ }^{170}$ Due to the racialisation of CSE and its vague and inconsistent parameters, ${ }^{171}$ there are discussions to be had as to whether the term has outlived its usefulness and should be abandoned in favour of CSA: the more neutral, inclusive and clearly-defined term. Note that inclusivity does not preclude focusing specific analyses or interventions on specific issues: disaggregation, precision and context-specificity are vital in tackling crimes. Nevertheless, data and their collection are not neutral and any categorisation or typologies must be theoretically and methodologically solid and not built up around racial stereotypes.

Third, the fixation on the 'uniquely dangerous masculinities of Muslim men'172 encourages hyper-simplistic and inaccurate understandings of how and why abuse occurs. Rates of CSA are high across different countries and groups, undermining the notion that certain groups are inherently more abusive than others. ${ }^{173}$ Although traditionally approached through the lens of individual psychopathology, decades of research into CSA show that offenders are remarkably heterogeneous and there are few meaningful individual-level predictors. ${ }^{174}$ Recognition is growing - albeit not yet mainstream - that CSA, like any human behaviour, results from an interaction between individuals and their environments. ${ }^{175}$ Although people differ in their propensity to offend, their opportunities to do so are moderated by a whole host of factors, among them demographic, familial, cultural, occupational, institutional and structural considerations. ${ }^{176}$ These intersecting factors help explain why certain groups can be differentially represented in certain offending contexts, without meaning factors like ethnicity (or indeed religion) are in themselves causal. An increased focus on opportunities also opens up new avenues to intervention, such as contextual safeguarding. ${ }^{177}$ An approach to understanding and tackling harm outside the family, contextual safeguarding 
considers the immediate physical and social environments in which harm occurs and how places and practices might be modified to reduce risk and build resilience. Greater adoption of such approaches would help shift away from generic 'prevention' through one-size-fits-all awareness-raising or education at one end of the spectrum and prosecution at the other. Although prosecution is important - not least symbolically - it comes too late when harm is already done, has limited deterrent effect and makes little overall dent in crime. ${ }^{178}$ Moreover, CSA is clearly not something for the police alone to tackle: other parties (e.g. health, social care, education, charities, community groups, families) have vital roles to play and their contributions must be encouraged.

Fourth, the misapprehension that 'grooming gangs' flourished primarily due to 'political correctness' must be tackled. Decrying political correctness (usually in the context of racialised minorities) is common among rightwing and far-right commentators but detracts from broader systemic issues that require attention. ${ }^{179}$ Responses to CSE in general have suffered widespread and well-documented problems. ${ }^{180}$ Before interest in 'grooming gangs' exploded, CSE was probably fairly easy to ignore because of low reporting levels, limited understanding, low prioritisation and victims' lack of social capital. Long-standing concerns existed that police and particularly prosecutors were reluctant to pursue cases for fear victims would not make credible witnesses. ${ }^{181}$ Moreover, unsympathetic attitudes to sexually exploited children likely reflect broader prejudices around who constitutes a credible and 'deserving' victim. ${ }^{182}$ Remember too that rape myths and victim blaming are not confined to criminal justice and child protection professionals: they are common among the general public. ${ }^{183}$

Fifth, CSE can be challenging and costly to investigate and prosecute. Years of austerity measures have hit criminal justice agencies hard, ${ }^{184}$ meaning they may not be adequately resourced, trained and incentivised to respond as effectively as possible to sexual offences. Police and prosecutors involved in major CSE cases indeed described them as unusually complex and resource-intensive. ${ }^{185}$ They also flagged tensions with performance management culture, stating for example that the extent of victim care 'just doesn't match up against any [policing] performance indicators' or that pursuing difficult cases conflicts with 'serious performance pressure' in the CPS to win as many sexual offence cases as possible. ${ }^{186}$ Changes in policy and top-down mandates around CSE must be matched by adequate resourcing and proper accommodation of its complexities. Since law enforcement-led approaches play a central role at present, they should be improved wherever possible. In making the above recommendations, we acknowledge that 'women of color, immigrant, queer, transgender, poor, and other marginalized women are often further brutalized - rather than protected by the police'. ${ }^{187}$ The role and indeed capacity of police and the criminal justice system to prevent sexual violence have long been called into question by abolitionists and other campaigners, drawing upon a history of state and institutional failure in dealing with violence against women and girls (VAWG). ${ }^{188}$ One legacy 
of such failures has been the attempts by some groups to develop grassroots, community-based approaches to dealing with sexual violence that directly challenge approaches (described as 'dominant feminisms') that readily invoke the tools of the 'carceral state'. ${ }^{189}$ As Phipps argues, it is women of colour who have long been doing this largely unacknowledged intersectional work at the grassroots: 'These activists understand that single-issue politics is not resistance, that feminism which does not centre the most marginalised is not fit for purpose.' 190 We recognise the limits of police-led approaches (practically and politically) in addressing CSA and call for greater investment in the funding of specialist VAWG services - particularly those developed for and led by marginalised groups.

The sixth issue then, especially important when considering alternative approaches rooted in a commitment to anti-racist feminism, is that the impacts of austerity are also evident in the chronic underfunding of support services for victims and survivors of sexual offences. In Rotherham, the focus of so much attention, counselling services are reportedly extremely oversubscribed with waiting times averaging seven months. ${ }^{191}$ The government's past and proposed spending on sexual offence support services ${ }^{192}$ is dwarfed by the outlay on figurehead inquiries and investigations. For example, the total funding for rape crisis services across England and Wales was just $£ 7.2$ million in 2018/19,193 compared with Operation Stovewood's budget of $£ 12$ million. ${ }^{194}$ We reject Boris Johnson's outrageous characterisation of investigations into non-recent child sexual abuse as 'spaffing' money. ${ }^{195}$ There are, however, difficult conversations to be had about how finite funds can be spent most effectively for current, past and future victims. Specialist CSE services for BME victims are reportedly particularly underfunded. ${ }^{196}$ Despite calls for more inclusive responses, ${ }^{197}$ a recent review found 'little evidence about how sexual violence interventions in the UK accommodate diversity or pay attention to issues of race, ethnicity, class, sexuality or disability'. ${ }^{198}$ Looking beyond CSE to the broader VAWG sector, Imkaan's recent report is a damning indictment of chronic underfunding of long-established, specialist services. Imkaan, the UK's only second-tier organisation dedicated to addressing violence against BME women, describes BME VAWG services as,

'the poor relation' of the wider ending VAWG movement. The sector has a long history of underfunding and political marginalisation, which for individual organisations has impacted their survival and their ability to sustain the vital work that they do. ${ }^{199}$

Shortfalls in funding for VAWG services require urgent redress, particularly where unique, specialist services for BME clients are concerned. Spending is often directed towards generic, cheaper (and, more often than not, white-led) organisations at the expense of specialist BME services, creating not just an inequality of funding but an inequality of services that deprives minorities of the support they need. ${ }^{200}$ 
Finally, the 'grooming gangs' discourse should be addressed by a genuine engagement with anti-racist feminism perspectives. Racial stereotyping has undoubtedly led to fractures within anti-racist and feminist movements, which are themselves marked by attempts by Black and Asian women to organise on their own terms against sexual abuse, racism and patriarchy. ${ }^{201}$ It also affects the capacity of minority groups to discuss preventing sexual abuse without fuelling racist stereotyping and scapegoating. ${ }^{202}$ As Gopal argues, contradictions within activist communities need to be confronted too since '[i]t is, of course, perfectly possible to be racist in the name of feminism or misogynist while laying claim to antiracism' ${ }^{203}$ Backlash around Sarah Champion's outrageous article for The Sun (discussed earlier) demonstrated that some activists, politicians and the wider public are at least alert and responsive to attempts to whip up racist animosity against Muslim minorities. The processes of racialisation examined in this article obscure from view institutional failures, contemptible attitudes towards victims, many of them working-class girls and young women, and a reluctance to acknowledge that austerity-related cuts have decimated services dedicated to tackling sexual abuse and violence. ${ }^{204}$ Culturalist, essentialist explanations of why Muslim men sexually abuse children must be rejected. Reliant on multitudinous racial stereotypes, they exceptionalise sexual abuse as the preserve of particular communities rather than acknowledging it is an everyday problem across British society. As Grewal notes, 'Muslim men are not considered sufficiently developed individuals who could actively decide on their actions. They are completely at the mercy of their culture, which is itself understood as one based upon violence against women, misogyny and lack of respect for individual autonomy.'205 Culturalist understandings thus impede genuine work to tackle sexual violence by 'justifying' initiatives 'that have to do more with teaching "them" how to behave than it does any meaningful anti-violence objective'. ${ }^{206}$

\section{Acknowledgements}

The authors would like to thank the anonymous reviewers of this article and Ella Cockbain would like to thank all those who gave her advice and encouragement when she was facing a nasty backlash after critiquing Quilliam's report: your support meant a lot. This article was not funded by any particular grant and we have no conflicts of interest to declare.

\section{References}

1 A. Sivanandan, 'From resistance to rebellion', Race EClass 23, no. 2/3 (Winter 1981), pp. 111-52.

2 A. Kundnani, 'From Oldham to Bradford: the violence of the violated', Race $\mathcal{E}$ Class 43, no. 2 (2001), pp. 105-10.

3 E. Cockbain, 'Grooming and the "Asian sex gang predator": the construction of a racial crime threat', Race \& Class 54, no. 4 (Apr-June 2013), pp. 22-32.

4 See Cockbain, 'Grooming and the "Asian sex gang predator"' and E. Cockbain, 'When bad evidence is worse than no evidence: Quilliam's "grooming gangs" report and its legacy', Policing Insight, 20 March 2019, https://policinginsight.com/analysis/when-bad-evidenceis-worse-than-no-evidence-quilliams-grooming-gangs-report-and-its-legacy/. 
5 Although there is a specific offence under English and Welsh law of 'meeting a child following sexual grooming', it differs greatly from popular conceptions of 'grooming gang offences'. It is both fairly infrequently used and appeared primarily designed for use around online grooming and travelling child sex offenders. See L. Kelly and K. Karsna, Measuring the scale and changing nature of child sexual abuse and child sexual exploitation, scoping report (London: London Metropolitan University and Centre of Expertise on Child Sexual Abuse, 2018).

6 See Cockbain, 'Grooming and the "Asian sex gang predator"' and Cockbain, 'When bad evidence is worse than no evidence'.

7 In practice, the label 'CSE' seems most commonly associated with older children who are abused outside the family context, E. Cockbain, M. Ashby and H. Brayley, 'Immaterial boys? A large-scale exploration of gender-based differences in child sexual exploitation service users', Sexual Abuse: a journal of research and treatment 29, no. 7 (2015), pp. 658-84; E. Cockbain, Offender and Victim Networks in Human Trafficking (Abingdon: Routledge, 2018); Kelly and Karsna, Measuring the scale; K. Mitchell et al., 'Rethinking research on sexual exploitation of boys: methodological challenges and recommendations to optimize future knowledge generation', Child Abuse and Neglect 66 (2017), pp. 142-51.

8 Kelly and Karsna, Measuring the scale.

9 Cockbain, 'Grooming and the "Asian sex gang predator"' and Cockbain, 'When bad evidence is worse than no evidence'.

10 S. Hall et al., Policing the Crisis: mugging, the state and law and order (London: Macmillan, 1978).

11 V. M. Rios, 'The hypercriminalization of Black and Latino male youth in the era of mass incarceration', in M. Marable, I. Steinberg and K. Middlemass (eds), Racializing Justice, Disenfranchising Lives: the racism, criminal justice, and law reader (New York: Palgrave Macmillan, 2007), pp. 17-33.

12 K. Yamahtta-Taylor, 'Why should we trust you? Clinton's big problem with young black Americans', The Guardian, 21 October 2016, https:/ / www.theguardian.com/us-news/2016/ oct/21/hillary-clinton-black-millennial-voters.

13 G. Bhattacharyya, Dangerous Brown Men: exploiting sex, violence and feminism in the 'War on Terror' (London: Zed Books, 2008); W. Tufail, 'Rotherham, Rochdale, and the racialised threat of the "Muslim Grooming Gang"', International Journal for Crime, Justice and Social Democracy 44, no. 3 (2015), pp. 30-43.

14 A. Norfolk, 'Revealed: conspiracy of silence on UK sex gangs', The Times, 5 January 2011, http://www.thetimes.co.uk/tto/news/uk/crime/article2863058.ece.

15 A. Norfolk, 'Barnardo's demands inquiry into sex exploitation of British girls', The Times, 5 January 2011, https://www.thetimes.co.uk/article/barnardos-demands-inquiry-into-sexexploitation-of-british-girls-10k8q33dsrf.

16 Cockbain, 'Grooming and the "Asian sex gang predator"', p. 30.

17 A. K. Gill and K. Harrison, 'Child grooming and sexual exploitation: are South Asian men the UK media's new folk devils?', International Journal for Crime, Justice and Social Democracy 4, no. 2 (2015), p. 43.

18 Formerly a reporter and editor, Brian Cathcart is now Professor of Journalism at Kingston University. He is also a founder and ex-director of Hacked Off, which campaigns in the UK for a free and accountable press. Paddy French is a former current affairs producer, who now edits the Press Gang website: an independent investigative website that exposes rogue journalism. See B. Cathcart and P. French, UNMASKED: Andrew Norfolk, The Times Newspaper and Anti-Muslim Reporting - a case to answer (London: Unmasked Books, 2019).

19 In which Norfolk, writing in The Times, misleadingly claimed a 'white Christian child' was left distressed after being placed in Muslim households in Tower Hamlets. The press regulator upheld a complaint against the article, headlined 'Christian child forced into Muslim foster care' (see https://www.theguardian.com/media/2018/apr/24/complaint-upheldover-times-story-about-london-girl-fostered-with-muslim-family). 
20 Cathcart and French, UNMASKED, p. 2.

21 Cathcart and French, UNMASKED, pp. 5-6.

22 'The Times view on media campaigners and Andrew Norfolk: Press Gang', The Times, 27 June2019, https:// www.thetimes.co.uk/article/ the-times-view-on-media-campaigners-and-andrew -norfolk-press-gang-7fd352sds.

23 E. Cockbain, 'Grooming and the "Asian sex gang predator"'; Gill and Harrison, 'Child grooming and sexual exploitation'; T. Patel, 'Cultural repertoires and modern menaces: the media's racialised coverage of child sexual exploitation', in M. Bhatia, S. Poynting and W. Tufail (eds), Media, Crime and Racism (London: Palgrave Macmillan, 2018), pp. 33-47; W. Tufail and S. Poynting, 'Muslim and dangerous: "Grooming" and the politics of racialisation', in D. Pratt and R. Woodlock (eds), Fear of Muslims?: international perspectives on Islamophobia (Basel: Springer International Publishing, 2016).

24 Note that rigorous empirical research is needed to examine the extent to which such terms are reserved for ethnic minority offenders. Our crude searches are intended for illustrative purposes only: we have not searched extensively for synonyms or screened results for irrelevant or duplicative material. Search conducted 15 October 2019 on Nexis (formerly LexisNexis) using the keyword 'grooming gang*' between a) 05/01/02-04/01/11 and b) 05/01/11$15 / 10 / 19$ (a broadly equivalent but slightly shorter period). The * is a search convention that denotes that a word may be truncated (i.e. gang* would also return gangs). The database covers newspapers, blogs, videos, etc. The majority of results $(69 \%, n=3,929)$ came from UK sources.

25 The subset of results also featuring one or more of the (fairly modest set of) keywords Muslim*, Islam*, Asian* or Pakistan* ( $n=3,073,54.4 \%)$.

26 Crown Prosecution Service, Interim Guidance on Prosecuting Cases of Child Sexual Abuse (London: CPS, 2013).

27 S. Miah, 'The groomers and the question of race', Identity Papers: a journal of British and Irish studies 1, no. 1 (2015), pp. 54-66; Patel, 'Cultural repertoires and modern menaces'; Tufail, 'Rotherham, Rochdale and the racialised threat'; W. Tufail, 'Media, state and "political correctness": the racialisation of the Rotherham child sexual abuse Scandal', in M. Bhatia et al. Media, Crime and Racism (pp. 49-71); Tufail and Poynting, 'Muslim and dangerous'.

28 Miah, 'The groomers and the question of race'.

29 Tufail, 'Media, state and "political correctness"'.

30 Cockbain, 'Grooming and the "Asian sex gang predator"'.

31 Cockbain, 'Grooming and the "Asian sex gang predator"'.

32 M. Salter and S. Dagistanli, 'Cultures of abuse: "sex grooming", organised abuse and race in Rochdale, UK', International Journal for Crime, Justice and Social Democracy 4, no. 2 (2015), p. 54.

33 Tufail, 'Media, state and "political correctness"'; Tufail and Poynting, 'Muslim and dangerous'.

34 A. Lentin, 'Europe and the silence about race', European Journal of Social Theory 11, no. 4 (2008), pp. 487-503; Patel, 'Cultural repertoires and modern menaces'; J. Solomos and L. Back, 'Conceptualising racisms: social theory, politics and research', Sociology 28, no. 1 (1994), pp. 143-61; Tufail, 'Media, state and "political correctness"'.

35 S. Champion, 'British Pakistani men ARE raping and exploiting white girls . . . and it's time we faced up to it', The Sun, 10 August 2017, https:/ / www.thesun.co.uk/news/4218648/ british-pakistani-men-raping-exploiting-white-girls/.

36 W. Tufail, 'The racialised and Islamophobic framing of the Rotherham and Rochdale child sexual abuse scandals', in I. Awan and I. Zempi (eds) The Routledge Handbook of Islamophobia (Abingdon: Routledge, 2019), pp. 147-60); JUST Yorkshire, A Temperature Check Report: understanding and assessing the impact of Rotherham MP, Sarah Champion's comments in the Sun newspaper on 10 August 2017 (Bradford: JUST Yorkshire, 2018).

37 J. Elgot and G. Ruddick, 'Sarah Champion distances herself from Sun article on British Pakistani men', The Guardian, 16 August 2017, https:/ / www.theguardian.com/politics/2017/aug/16/ sarah-champion-complaint-sun-article-british-pakistani-men. 
38 G. Ruddick, 'Press watchdog clears Sun writer who referred to "the Muslim problem"', The Guardian, 23 November 2017, https://www.theguardian.com/media/2017/nov/23/presswatchdog-clears-sun-writer-who-referred-to-the-muslim-problem.

39 BBC News, “The Sun cleared over "Muslim Problem" Trevor Kavanagh article', BBC News, 23 November 2017, https://www.bbc.co.uk/news/uk-42102361.

40 A. Cowburn, 'Jeremy Corbyn "wrong to sack" Sarah Champion over Sun article on British Pakistani men, says Sajid Javid', The Independent, 17 August 2017, https://www.independent.co.uk/news/uk/politics/sajid-javid-says-jeremy-corbyn-wrong-to-dismiss-equalitiesminister-over-sun-newspaper-article-on-a7897956.html.

41 The letter can be viewed at: https://static1.squarespace.com/static/59d3becfa803bb9c37 126c3e/t/5b56fe90352f53339a70bdc1/1532427923797/Ho+Response.pdf.

42 Cockbain, 'When bad evidence is worse than no evidence'.

43 Cockbain, 'When bad evidence is worse than no evidence'.

44 A. Norfolk, 'Sajid Javid orders research into ethnic origin of sex grooming gangs', The Times, 26 July 2018, https://www.thetimes.co.uk/article/sajid-javid-orders-research-into-ethnicorigin-of-sex-grooming-gangs-v97lc5mdk.

45 Cockbain, 'When bad evidence is worse than no evidence'.

46 A. Mohdin, 'Sajid Javid lambasted for "Asian paedophiles" tweet', The Guardian, 20 October 2018, https:/ / www.theguardian.com/politics/2018/oct/20/sajid-javid-lambasted-for-asian -paedophiles-tweet-huddersfield.

47 M. Okwonga, 'The Dangers of Priti Patel's racial gatekeeping', Byline Times, 3 October 2019, https:// bylinetimes.com/2019/10/03/the-dangers-of-priti-patels-racial-gatekeeping/.

48 See D. Miller, 'Sikh peer accuses BBC of "prejudice" as he quits Radio 4 show after 35 years', The Scotsman, 4 October 2019, https:/ / www.scotsman.com/news/ people/sikh-peer-accusesbbc-of-prejudice-as-he-quits-radio-4-show-after-35-years-1-5017507. Interestingly, the material in question related to the 'forced conversion' narrative, which has been discredited by Sian (see later in this article).

49 See A. McSmith, 'Howard sacks peers for endorsing UKIP', The Independent, 30 April 2004, https:/ / www.independent.co.uk/news/uk/politics/howard-sacks-peers-for-endorsingukip-8002496.html.

50 Hansard, 'Grooming gangs, House of Lords debate', Vol. 797 (London: Hansard, 14 May 2019). Available at: https://hansard.parliament.uk/Lords/2019-05-14/debates/349FA275CB65-45C0-87C7-EE16D1FD1B0A/GroomingGangs.

51 Cockbain, 'Grooming and the "Asian sex gang predator"'.

52 A. Meleagrou-Hitchens and H. Brun, A Neo Nationalist Network: the English Defence League and Europe's Counter-Jihad Movement (London: King's College London, 2013), p. 61.

53 P. McLoughlin, Easy Meat: inside Britain's grooming gang scandal (2016) was published by the New English Review Press, the publishing arm of a conservative magazine heavily involved in the 'counter-jihad' movement (pp. 1, 24). See, e.g., http://powerbase.info/index.php/ New_English_Review.

54 See https://www.independent.co.uk/news/uk/home-news/amazon-ban-tommy-robinson -website-koran-a8812111.html

55 Meleagrou-Hitchens and Brun, A Neo Nationalist Network, p. 61.

56 The UK Independence Party (UKIP) was originally set up by disaffected Conservatives including Nigel Farage as a home for anti-immigrant Eurosceptics. Under Gerald Batten, its leader from April 2018 to June 2019, it morphed from rightwing to far-right and today campaigns on a largely anti-Muslim platform. P. Walker, 'Tommy Robinson appointed as UKIP's "grooming gangs adviser"', The Guardian, 22 November 2018, https://www.theguardian. com/politics/2018/nov/22/tommy-robinson-ukip-grooming-gangs-adviser.

57 M. Day, 'Czech ruling party distances itself from invitation to Tommy Robinson to speak in parliament amid outcry', The Telegraph, 5 April 2019, https://www.telegraph.co.uk/ news/2019/04/05/czech-ruling-party-distances-invitation-tommy-robinson-speak/. 
58 "“Senior member" of English Defence League jailed for sexually abusing 10-year-old girl', The Independent, 27 February 2018, https://www.independent.co.uk/news/uk/crime/edlenglish-defence-league-leigh-mcmillan-jailed-paedophile-old-bailey-a8231231.html.

59 L. Dearden, 'Tommy Robinson caused Huddersfield grooming gang member to appeal conviction, court ruling reveals', The Independent, 9 July 2019, https:/ / www.independent.co.uk/ news/uk/crime/tommy-robinson-court-case-facebook-live-video-judge-latest-a8996626.html.

60 Cockbain, Offender and Victim Networks; L. Kelly, J. Lovett and L. Regan, A gap or a chasm? Attrition in reported rape cases (London: Home Office Research, 2005).

61 Cockbain, 'Grooming and the "Asian sex gang predator"'; Dearden, 'Tommy Robinson caused Huddersfield grooming gang member to appeal conviction, court ruling reveals'.

62 H. Rafiq and M. Adil, Group-Based Child Sexual Exploitation: Dissecting 'Grooming Gangs' (London: Quilliam, 2017). In this and the following paragraphs, page references to the report are given in the text.

63 Haras Rafiq is CEO of the controversial Quilliam Foundation. His claimed expertise is in the area of countering extremism. Muna Adil is listed as a researcher with the Quilliam Foundation. Neither appear to have any relevant scientific or professional training or expertise to conduct a study on CSE.

64 The organisation released a commentary and a letter from their IT company vehemently denying changes (available at: http://journal.quilliaminternational.com/2018/11/10/letter-frompioneer-solutions/), but the metadata on the two different versions of the report expose the lies.

65 Cockbain, 'When bad evidence is worse than no evidence'.

66 Rafiq and Adil, Group Based Child Sexual Exploitation, p. 18.

67 No workable research definition was provided and three different descriptors were used (each of which would have a different remit): "'grooming gang" offences', 'group-based localised street grooming of young girls' and 'all group child-sex offences'.

68 Child Exploitation and Online Protection Centre, Threat Assessment of Child Sexual Exploitation and Abuse (London: CEOP, 2013).

69 R. Reiner, 'Media-made criminality: the representation of crime in the mass media', in M. Maguire, R. Morgan and R. Reiner (eds), The Oxford Handbook of Criminology (Oxford: Oxford University Press, 2011), pp. 376-416.

70 Hall et al., Policing the Crisis.

71 K. Bhatti-Sinclair and C. Smethurst, 'Understanding group localised child sexual exploitation', Seen and Heard Journal 28, no. 4 (2018), pp. 41-54; K. Bhatti-Sinclair and C. Sutcliffe, 'Group localised child sexual exploitation: identifying those who have been prosecuted', Preprint (2018), https:/ / papers.ssrn.com/sol3/papers.cfm?abstract_id=3248665.

72 Cockbain, 'When bad evidence is worse than no evidence'; J. Spooner and J. Stubbs, 'Grooming gangs: Quilliam and the myth of the 84 percent', Medium, 25 January 2018, https://medium. com/@Reg_Left_Media/grooming-gangs-quilliam-the-myth-of-the-84-percent-cc834b57fcf3.

73 Cockbain, 'When bad evidence is worse than no evidence'.

74 N. Ahmed, 'The Quilliam Foundation is financed by Tea-Party conservatives investigated by Sam Harris', Medium, 8 January 2016, https://medium.com/insurge-intelligence/thequilliam-foundation-is-financed-by-tea-party-conservatives-investigated-by-sam-harris1e43d54f0bee; N. Malik, 'Islam's New “Native Informants"', The New York Review of Books, 6 June 2018, https://www.nybooks.com/daily/2018/06/07/islams-new-native-informants/; B. Quinn, 'Tommy Robinson link with Quilliam Foundation raises questions', The Guardian, 12 October 2013, https://www.theguardian.com/uk-news/2013/oct/12/tommy-robinsonquilliam-foundation-questions-motivation.

75 Malik (2018) is a rare exception to the lack of mainstream scrutiny.

76 S. Forsdick, 'Sunday Times headline “Asians make up 80 per cent of child groomers" breached standards code, IPSO rules', The Press Gazette, 20 April 2018, https://www.pressgazette. co.uk/Sunday-times-headline-asians-make-up-80-per-cent-of-child-groomers-breachedstandards-code-ipso-rules/. 
77 A. Pearson, 'It's not racist to tell the truth about grooming gangs', The Telegraph, 12 December 2017, https:/ / www.telegraph.co.uk/women/politics/not-racist-tell-truth-grooming-gangs/.

78 ITV News, 'UKIP spokesman accused of being "alarmist" after calling grooming gangs "holocaust of our children"', ITV News, 21 September 2018, https:/ /www.itv.com/news/2018-0921/muslim-sex-gangs-responsible-for-holocaust-of-our-children-claims-ukip/.

79 Hansard, House of Lords, Child Sexual Exploitation: Grooming Gangs, Volume 789, 13 March 2018 (London: Hansard, 2018). Available at: https:/ / hansard.parliament.uk/Lords/2018-0313/debates/AA1542AD-0A4F-4A1B-B93E-695AADDA26C2/ChildSexualExploitationGroo mingGangs?highlight=quilliam--contribution-CAC4B4E1-D327-412E-9FE6-80C0A2D4F26E.

80 A. Lawton, 'Planned contempt of court statement by Tommy Robinson', 2018, https://www. andrewlawton.ca/planned-contempt-of-court-statement-by-tommy-robinson/.

81 SYUK, The Religiously Aggravated Sexual Exploitation of Young Sikh Women Across the UK (Birmingham: S.M.A.R.T. and SYUK, 2018).

82 A. Lusher, 'Influential Sikh youth group associating with far-right EDL founder Tommy Robinson', The Independent, 16 October 2017, https://www.independent.co.uk/news/uk/ home-news/ sikh-youth-uk-muslim-film-university-tommy-robinson-edl-sex-groomersislamophobia-racism-a8002526.html.

83 Rafiq and Adil, Group Based Child Sexual Exploitation.

84 M. Dathan, 'ABUSE IGNORED Sexual exploitation of British Sikh girls by Muslim men has been "ignored" by police due to "political correctness"', The Sun, 25 November 2018, https:/ / www.thesun.co.uk/news/7825480/sexual-exploitation-sikh-girls-ignored-police/.

85 See, e.g., https://twitter.com/SikhYouthUK_/status/966747298800775169?s=20.

86 L. Dearden, 'Sikh Youth UK founder and sister charged with charity funding offences by terror police', The Independent, 30 September 2019, https:/ / www.independent.co.uk/news/uk/ crime/sikh-youth-uk-arrested-terror-police-sister-deepa-singh-a9127046.html.

87 SYUK, The Religiously Aggravated Sexual Exploitation, pp.11, 31.

88 K. Sian, "“Forced" conversions in the British Sikh diaspora', South Asian Popular Culture 9, no. 2 (2011), pp. 115-30; K. Sian, Unsettling Sikh and Muslim Conflict: mistaken identities, forced conversions, and postcolonial formations (Washington, DC: Lexington Books, 2013).

89 J. Jhutti-Johal and S. Hundal, 'The changing nature of activism among Sikhs in the UK today' (London: Independent Commission for Countering Extremism, 2019).

90 Hansard, Grooming Gangs.

91 L. Fekete, 'The Muslim conspiracy theory and the Oslo massacre', Race \& Class 53, no. 3 (2011), pp. 30-47.

92 This term is a curious and facile linguistic device that seeks to connect fascism and Islamist extremism. It emerged in the early 1990s, was popularised by former US President George W. Bush in launching his 'war on terror' and has since been adopted by various rightwing, liberal and even feminist commentators, see Fekete, 'The Muslim conspiracy theory'; S. Zemni, 'The shaping of Islam and Islamophobia in Belgium, Race \& Class 53, no. 1 (2011), pp. 28-44.

93 A. Kundnani, 'Islamism and the roots of liberal rage', Race \& Class 50, no. 2 (2008), pp. 40-68.

94 S. Hussein and S. Poynting, 'We're not multicultural, but. . .', Journal of Intercultural Studies 38, no. 3 (2017), pp. 333-48; S. Poynting and A. Mason, 'The new integrationism, the state and Islamophobia: retreat from multiculturalism in Australia', International Journal of Law, Crime and Justice 36, no. 4 (2008), pp. 230-46; A. Kundnani, 'Integrationism: the politics of antiMuslim racism', Race \& Class 48, no. 4 (2007), pp. 24-44.

95 A. Kundnani, The Muslims Are Coming! Islamophobia, extremism and the domestic war on terror (London: Verso, 2014).

96 U. M. Vieten, 'Far right populism and women: the normalisation of gendered anti-Muslim racism and gendered culturalism in the Netherlands', Journal of Intercultural Studies 37, no. 6 (2016), pp. 621-36; U. M. Vieten and S. Poynting, 'Contemporary far right racist populism in Europe', Journal of Intercultural Studies 37, no. 6 (2016), pp. 533-40. 
97 S. Keskinen, 'Borders of the Finnish nation: media, politics and rape by "foreign" perpetrators', in E. Eide and K. Nikunen (eds), Media in Motion: cultural complexity and migration in the Nordic region (Farnham: Ashgate, 2011), pp. 107-24.

98 Keskinen, Borders of the Finnish Nation.

99 Keskinen, Borders of the Finnish Nation.

100 S. Dagistanli and K. Grewal, 'Perverse Muslim masculinities in contemporary orientalist discourse: the vagaries of Muslim immigration in the West', in G. Morgan and S. Poynting (eds) Global Islamophobia: Muslims and moral panic in the West (Surrey: Ashgate, 2012), p. 126.

101 S. Farris, In the Name of Women's Rights: the rise of Femonationalism (Durham, NC: Duke University Press, 2017), p. 4.

102 The term 'femocrat' refers to female bureaucrats.

103 B. Whelan, 'Britain's far right collapses amid infighting and legal woes', Channel 4 News, 12 January 2013, https://www.channel4.com/news/britains-far-right-collapses-amid-infighting-and-legal-woes.

104 S. Israel, 'Rotherham trial: far right activists in the spotlight', Channel 4 News, 20 October 2016, https://www.channel4.com/news/by/simon-israel/blogs/activists-bent-targeting-asians.

105 L. Blissett, 'Why you should oppose the far right march on October 13th', Red Pepper, 9 October 2018, https://www.redpepper.org.uk/why-you-should-oppose-the-democraticfootball-lads-alliance-on-october-13th/.

106 Image of the flyer quote-tweeted here (https://twitter.com/TjayJT/status/105704708518968 1152 ?s=2) but the original has since been deleted. Photo of it available on request.

107 K. Razzall and Y. Khan, 'Far-right and far-left extremists use abuse for own agenda - Sarah Champion', BBC News, 20 December 2018, https://www.bbc.co.uk/news/uk-46635022.

108 B. Quinn, 'Tommy Robinson given nine-month jail sentence for contempt of court', The Guardian, 11 July 2019, https:/ / www.theguardian.com/uk-news/2019/jul/11/tommy-robinson-given-nine-month-jail-term-for-contempt-of-court.

109 J. Halliday, L. Beckett and C. Barr, 'Revealed: the hidden global network behind Tommy Robinson', The Guardian, 7 December 2018, https:/ /www.theguardian.com/uk-news/2018/ $\mathrm{dec} / 07 /$ tommy-robinson-global-support-brexit-march.

110 J. Mayer, Dark Money: how a secretive group of billionaires is trying to buy political control in the US (London: Scribe, 2016).

111 T. Griffin, 'The problem with the Quilliam Foundation', Open Democracy, 7 November 2016, https:// www.opendemocracy.net/en/opendemocracyuk/problem-with-quilliamfoundation/.

112 C. A. Bail, Terrified: how anti-Muslim fringe organizations became mainstream (Princeton, NJ and Oxford: Princeton University Press, 2015); N. Massoumi, T. Mills and D. Miller (eds) What Is Islamophobia? Racism, social movements and the state (London: Pluto Press, 2017); N. Lean and J. L. Esposito, The Islamophobia Industry: how the Right manufactures fear of Muslims (London: Pluto Press, 2012).

113 S. Poynting, 'What caused the Cronulla riot?', Race \& Class 48, no. 1 (2006), pp. 85-92; Tufail, 'Media, state and "political correctness"'.

114 In 2015, child sexual exploitation and abuse was identified as a 'national threat' in the Strategic Policing Requirement: a status that mandates that all police forces in England and Wales must pay attention to a given issue and is thus intended to encourage its prioritisation (HM Government, 2015).

115 For example, Child Exploitation and Online Protection Centre, Out of Mind, Out of Sight: breaking down the barriers to understanding child sexual exploitation (London: CEOP, 2011); Child Exploitation and Online Protection Centre, Threat Assessment of Child Sexual Exploitation and Abuse (London: CEOP, 2013); HM Government, Tackling Child Sexual Exploitation (London: HM Government, 2015); HM Government, Child sexual exploitation: definition and a guide for practitioners, local leaders and decision makers working to protect children from child sexual 
exploitation (London: HM Government, 2017a); HM Government; Tackling Child Sexual Exploitation: progress Report. London: HM Government, 2017b).

$116 \mathrm{H}$. Bentley et al., How safe are our children? the most comprehensive overview of child protection in the UK (London: NSPCC, 2018).

117 Bentley et al., How safe are our children?; Kelly and Karsna, Measuring the scale.

118 H. Brayley and E. Cockbain, 'British children can be trafficked too: towards an inclusive definition of internal child sex trafficking', Child Abuse Review 23, no. 3 (2014), pp. 171-84; S. Clutton and J. Coles, Sexual Exploitation Risk Assessment Framework: a pilot study (Cardiff: Barnardo's, 2007); Cockbain et al, Immaterial Boys; E. Cockbain and H. Brayley, 'Child sexual exploitation and youth offending: a research note', European Journal of Criminology 9, no. 6 (2012), pp. 689-700; Office of the Children's Commissioner for England, 'I thought I was the only one. The only one in the world': the Office of the Children's Commissioner's inquiry into child sexual exploitation in gangs and groups, interim report (London: Office of the Children's Commissioner for England, 2012); A. Sidebottom et al., 'Missing children: risks, repeats and responses', Policing and Society (2019), pp. 1-14.

119 D. Barrett and M. Melrose, 'Courting controversy - children sexually abused through prostitution - are they everybody's distant relatives but nobody's children?', Child and Family Law Quarterly 15, no. 4 (2003), pp. 371-82; E. Chase and J. Statham, 'Commercial and sexual exploitation of children and young people in the UK - A review', Child Abuse Review 14, no. 1 (2005), pp. 4-25.

120 Cockbain, Offender and Victim Networks.

121 Barnardo's, Report of the Parliamentary inquiry into the effectiveness of legislation for tackling child sexual exploitation and trafficking within the UK (Barkingside: Barnardo's, 2014).

122 Kelly and Karsna, Measuring the scale.

123 Norfolk, 'Revealed: conspiracy of silence'.

124 Rafiq and Adil, Group Based Child Sexual Exploitation.

125 Annual average calculated based on the number of convicted offenders for the whole UK found by The Times over fourteen years $(n=56)$ and Quilliam twelve years $(n=264)$.

126 Kelly and Karsna, Measuring the scale.

127 J. Eaton, 'Logically I know I'm not to blame but I still feel to blame': exploring and measuring victim blaming and self-blame of women who have been subject to sexual violence, PhD (University of Birmingham, Birmingham, 2019); Kelly and Karsna, Measuring the scale; D. McNeish and S. Scott, Key Messages from Research on Children and Young People who Display Harmful Sexual Behaviours (London: Centre of Expertise on Child Sexual Abuse, 2018); Office for National Statistics, Abuse During Childhood: findings from the Crime Survey for England and Wales, year ending March 2016 (Newport: Office for National Statistics, 2016); L. Radford, S. Corral, C. Bradley, H. Fisher, C. Bassett, N. Howat and S. Collishaw, Child Abuse and Neglect in the UK Today (London: NSPCC, 2011).

128 Cockbain, 'Grooming and the "Asian sex gang predator"'.

129 Cockbain, 'When bad evidence is worse than no evidence'.

130 Child Exploitation and Online Protection Centre, Out of Mind, Out of Sight; Child Exploitation and Online Protection Centre, Threat Assessment; Office of the Children's Commissioner for England, I thought I was the only one.

131 Cockbain, 'Grooming and the "Asian sex gang predator"'; Kelly and Karsna, Measuring the scale.

132 Ministry of Justice, Statistics on Race and the Criminal Justice System 2016 (London: Ministry of Justice, 2017).

133 Cockbain, 'Grooming and the "Asian sex gang predator"'; S. Gohir, Unheard Voices: sexual exploitation of Asian girls and young women (Birmingham: Muslim Womens Network, 2013); Tufail, Rotherham, Rochdale and the Racialised Threat.

134 Cockbain et al., Immaterial Boys. 
135 Z. Ahmed in 'Finding a Voice: 40 years on', in A. Wilson, Finding a Voice: Asian women in Britain (Montreal: Daraja Press, 2018), pp. 204-09; C. Fox, 'It's not on the radar': the hidden diversity of children and young people at risk of sexual exploitation in England (Barkingside: Barnardo's, 2016); Gohir, Unheard Voices; C. McNaughton, C. Nicholls, E. Cockbain, H. Brayley, S. Harvey, C. Fox, C. Paskell and N. Jago, Research on the Sexual Exploitation of Boys and Young Men: a UK scoping study, summary of findings (Barkingside: Barnardo's, 2014).

136 Cockbain, 'Grooming and the "Asian sex gang predator"'; J. Harker, 'This is how racism takes root', The Guardian, 22 July 2012, https://www.theguardian.com/commentisfree/2012/ jul/22/how-racism-takes-root; Patel, 'Cultural repertoires and modern menaces'.

137 Kelly and Karsna, Measuring the scale.

138 Patel, 'Cultural repertoires and modern menaces'.

139 Cockbain, 'When bad evidence is worse than no evidence'.

140 Casually Quiet, Of Pigs and Men, (2019). Retrieved (with consent) from https:/ / twitter.com/ CasuallyQ/status/1086316320831008769 and reproduced with permission.

141 Tweet cited with permission. https://twitter.com/KateElysiaNWO/status/10506866943563 $24352 ? \mathrm{~s}=20$.

142 Tweet cited with permission. No hyperlink available as account is locked.

143 Tweet cited with permission. No hyperlink available as account is locked.

144 Tufail, 'Media, state and "political correctness"'.

145 Tufail, 'Media, state and "political correctness"', p. 66.

146 J. Halliday, 'Far right "infiltrating children's charities with anti-Islam agenda"', The Guardian, 5 March 2019, https://www.theguardian.com/world/2019/mar/05/far-right-infiltratingchildrens-charities-with-anti-islam-agenda.

147 Donations were solicited before registering as a charity. No data protection statement was in place before opening to calls and there was no information as to call handlers' suitability and vetting for the task.

148 Halliday, 'Far right "infiltrating children's charities with anti-Islam agenda"'.

149 We chose not to provide supporting references here because it was not possible to do so without identifying individuals and we felt it was not right to single people out in this context.

150 L. Fekete, The Muslim Conspiracy Theory and the Oslo Massacre, p. 34.

151 C. Lewis, 'Gunman in New Zealand terror attacks had "for Rotherham" written on ammo used in shootings', The Star, 15 March 2019, https://www.thestar.co.uk/news/gunman-innew-zealand-terror-attacks-had-for-rotherham-written-on-ammo-used-in-shootings-73571.

152 Cockbain, 'When bad evidence is worse than no evidence'.

153 L. Dearden, 'Darren Osborne: how Finsbury Park terror attacker became "obsessed" with Muslims in less than a month', The Independent, 2 February 2018, https:/ / www.independent. co.uk/news/uk/crime/darren-osborne-finsbury-park-attack-who-is-tommy-robinson-muslim-internet-britain-first-a8190316.html

154 Dearden, 'Darren Osborne: how Finsbury Park terror attacker became "obsessed" with Muslims in less than a month'.

155 Tufail and Poynting, 'Muslim and dangerous'.

156 Tufail, 'Media, state and "political correctness"'.

157 Tufail, 'Media, state and "political correctness"'; JUST Yorkshire, A Temperature Check Report.

158 J. Britton, 'Challenging the racialization of child sexual exploitation: Muslim men, racism and belonging in Rotherham', Ethnic and Racial Studies 42, no. 5 (2019), pp. 688-706.

159 Cockbain, Offender and Victim Networks.

160 BBC News, 'Mushin Ahmed death: Two men jailed over racist Rotherham killing', BBC News, 2016, https://www.bbc.co.uk/news/uk-england-south-yorkshire-35688543.

161 Tufail, 'Media, state and "political correctness"'.

162 Cockbain, 'Grooming and the "Asian sex gang predator"'; Tufail and Poynting, 'Muslim and dangerous'. 
163 J. Drew, An independent review of South Yorkshire Police's handling of child sexual exploitation 1997-2016 (Sheffield: S. Y. P. a. C. Commissioner, 2016).

164 C. Thomas, Are Juries Fair? (London: Ministry of Justice, 2010).

165 Kelly and Karsna, Measuring the scale.

166 Kelly and Karsna, Measuring the scale, p. 8.

167 Kelly and Karsna, Measuring the scale, p. 7.

168 D. Higgens, 'Rotherham abuse: investigation into grooming of teenagers to continue after six more men convicted, National Crime agency says', The Independent, 28 August 2019, https:/ / www.independent.co.uk/news/uk/crime/rotherham-grooming-gangs-abuse-nca-operation-stovewood-a9082941.html; L. Leeson, 'The fight against historical child sexual exploitation in Rotherham', The Yorkshire Post, 27 August 2019, https://www.yorkshirepost.co.uk/ news/crime/the-fight-against-historical-child-sexual-exploitation-in-rotherham-1-9956418.

169 Some exceptions include Fox, 'It's not on the radar'; J. Eaton 'British Pakistani Men raping White British Girls: bad apples or a bad barrel?', Victim Focus blog, 2 October 2017, https:/ / victimfocus.wordpress.com/2017/10/02/british-pakistani-men-raping-white-british-girlsbad-apples-or-a-bad-barrel/.

170 Kelly and Karsna, Measuring the scale.

171 Cockbain, 'Grooming and the "Asian sex gang predator"'; Cockbain et al., Immaterial Boys.

172 Tufail, 'Media, state and "political correctness"', p. 50.

173 N. Pereda. G. Guilera, M. Forns and J. Gómez-Benito, 'The international epidemiology of child sexual abuse: a continuation of Finkelhor (1994)', Child Abuse E Neglect 33, no. 6 (2009), pp. 331-42.

174 K. Kaufman, M. Mosher, H. Carter and L. Estes, 'An empirically based situational prevention model for child sexual abuse', in R. Wortley and S. Smallbone (eds), Situational Prevention of Child Sexual Abuse (Cullompton: Willan, 2006), pp. 101-44.

175 R. Wortley, 'Exploring the person-situation interaction in situational crime prevention', in N. Tilley and G. Farrell (eds), The Reasoning Criminologist: essays in honour of Ronald V. Clarke (Abingdon: Routledge, 2012), pp. 170-79.

176 Wortley et al., 'Exploring the person-situation interaction'.

177 C. Firmin, C. Warrington and J. Pearce, 'Sexual exploitation and its impact on developing sexualities and sexual relationships: the need for contextual social work interventions', The British Journal of Social Work 46, no. 8 (2016), pp. 2318-337.

178 D. M. Kennedy, Deterrence and Crime Prevention: reconsidering the prospect of sanction (Abingdon: Routledge, 2009).

179 Tufail, 'Media, state and "political correctness"'.

180 Barnardo's, Whose Child Now? Fifteen years of working to prevent the sexual exploitation of children in the UK (Barkingside: Barnardo's, 2009); Barnardo's, Puppet on a String: the urgent need to cut children free from sexual exploitation (Barkingside: Barnardo's, 2011); Barnardo's, Cutting Them Free: how is the UK progressing in protecting its children from sexual exploitation? (Barkingside: Barnardo's, 2012); H. Beckett, C. Firmin, P. Hynes and J. Pearce, Tackling Child Sexual Exploitation: a study of current practice in London (Luton: University of Bedfordshire, 2014); S. Jago and J. Pearce, Gathering Evidence of the Sexual Exploitation of Children and Young People: a scoping exercise (Luton: University of Bedfordshire, 2008).

181 Barnardo's, Puppet on a String; Child Exploitation and Online Protection Centre, Out of Mind, Out of Sight; Cockbain, Offender and Victim Networks; Crown Prosecution Service, Interim Guidance on Prosecuting Cases of Child Sexual Abuse (London: CPS, 2013); House of Commons, Child Sexual Exploitation and the Response to Localised Grooming (London: The Stationery Office, 2013).

182 Cockbain, Offender and Victim Networks; Kelly and Karsna, Measuring the scale.

183 Eaton, 'Logically I know I'm not to blame but I still feel to blame'; H. Taaffe, Sounds Familiar? (London: The Fawcett Society, 2017). 
184 N. Mann, P. Devendran and S. Lundrigan, 'Policing in a time of austerity: understanding the public protection paradox through qualitative interviews with police monitoring officers', Policing: A Journal Of Policy And Practice (2018).

185 Cockbain, Offender and Victim Networks.

186 Cockbain, Offender and Victim Networks, pp. 136, 143.

187 V. Law, 'Where abolition meets action: women organizing against gender violence', Contemporary Justice Review 14 (2011), p. 85.

188 B. Hudson, 'Restorative justice: the challenge of sexual and racial violence', Journal of Law and Society 25, no. 2 (1998), pp. 237-56.

189 E. Whalley and C. Hackett, 'Carceral feminisms: the abolitionist project and undoing dominant feminisms', Contemporary Justice Review 20, no. 4, pp. 456-73.

190 A. Phipps, 'The fight against sexual violence', Soundings: a journal of politics and culture 71 (2019), pp. 62-74.

191 Hansard, Grooming Gangs.

192 Ministry of Justice, ' $£ 5 m$ increase for rape and sexual abuse victims', Press release, Ministry of Justice, 2019, https://www.gov.uk/government/news/5m-increase-for-rape-and-sexualabuse-victims.

193 Department of Health, Home Office, Ministry of Justice, Prime Minister's Office, 10 Downing Street, \& The Rt Hon David Cameron, 'PM unveils tough new measures to tackle child sexual exploitation', press release, 2015, https://www.gov.uk/government/news/pm-unveilstough-new-measures-to-tackle-child-sexual-exploitation.

194 Higgens, 'Rotherham abuse'.

195 The term 'spaffing' is particularly insulting in this context as it is a slang word for ejaculating. E. Johnson, 'Letter to Boris Johnson', Rape Crisis Scotland, 2019, https:/ /www.rapecrisisscotland.org.uk/news/blog/a-letter-to-boris-johnson/.

196 Ahmed in 'Finding a Voice'; Gohir, Unheard Voices.

197 Fox, 'It's not on the radar'; McNaughton Nicolls et al., Research on the sexual exploitation of boys and young men.

198 S. Scott, D. McNeish, S. Bovarnick and J. Pearce, What Works in Responding to Child Sexual Exploitation (London: Centre of Expertise on Child Sexual Abuse, 2019).

199 Imkaan, From Survival to Sustainability: critical issues for the specialist black and 'minority ethnic' ending violence against women and girls sector in the UK, 2018, https:/ / docs.wixstatic.com/ugd /2f475d_9cab044d7d25404d85da289b70978237.pdf.

200 Imkaan, From Survival to Sustainability; L. Okolosie, 'Women of colour fleeing violence need help - not penalties for who they are', The Guardian, 4 January 2019, https:/ / www.theguardian.com/commentisfree/2019/jan/04/bme-women-violence-help-report-underfunding.

201 S. Siddiqui, 'Anti-racist feminism: engaging with the past', Race $\mathcal{E}$ Class 61, no. 2 (2019), pp. 96-104.

202 A. Davis, 'The color of violence against women', ColorLines 3, no. 3 (2000), https://www. colorlines.com/articles/color-violence-against-women; Y. Jiwani, 'Walking a tightrope: the many faces of violence in the lives of racialized immigrant girls and young women', Violence Against Women 11, no. 7 (2005), pp. 846-75; Gohir, Unheard Voices.

203 P. Gopal, 'Speaking with difficulty: feminism and antiracism in Britain after 9/11', Feminist Studies 39, no. 1 (2013), p. 103.

204 Tufail, Rotherham, Rochdale and the Racialised Threat; Imkaan, From Survival to Sustainability.

205 K. Grewal, 'Australia, the feminist nation? Discourses of gender, "culture" and nation in the "K brothers" gang rapes', Journal of Intercultural Studies 33, no. 5 (2012), p. 522.

206 S. Razack, 'Imperilled Muslim women, dangerous Muslim men, and civilized Europeans: legal and social responses to forced marriages', Feminist Legal Studies 12, no. 2 (2004), p. 131. 